\title{
PENGGUNAAN DIGITAL UNTUK MENINGKATKAN PEMASARAN PRODUK DIMASA PANDEMI PADA KARANG TARUNA KELURAHAN PAKU JAYA RT. 004 RW. 022
}

\author{
${ }^{1 *}$ Bachtiar Arifudin Husain, ${ }^{2}$ Arief Budi Santoso, ${ }^{3}$ Wiyanto \\ Universitas Pamulang, Tangerang Selatan, Banten, Indonesia \\ Email : *dosen01773@unpam.ac.id
}

Manuskrip: Desember -2021; Ditinjau: Januari -2022; Diterima: Januari -2022; Online: Januari-2022; Diterbitkan: Januari-2022

\begin{abstract}
ABSTRAK
Karang Taruna merupakan wadah pengembangan generasi muda nonpartisan, yang tumbuh atas dasar kesadaran dan rasa tanggung jawab social dari, oleh dan untuk masyarakat khususnya generasi muda di Karang Taruna, Kegiatan Pengabdian Kepada Masyarakat (PKM) untuk menumbuhkan sifat yang percaya diri serta untuk mempelajari penggunaan media Digital untuk meningkatkan pemasaran produk. Konsep digital marketing bagi para pelaku usaha yaitu dapat memasarkan produknya di mana saja dan kapan saja melalui internet. Fokus masalah yang diangkat, yaitu : (1) bagaimana strategi komunikasi pemasaran melalui digital marketing yang dilakukan oleh pelaku usaha kecil dan menengah (UKM) Di lingkungan Paku Jaya, dalam memasarkan produknya (2) bagaimana kendala dan manfaat penerapan digital marketing bagi pelaku usaha kecil dan menengah (UKM) Di lingkungan kelurahan Paku Jaya.
\end{abstract}

\section{Kata Kunci: Digitalisasi, Promosi, Komunikasi}

\section{PENDAHULUAN}

Pengabdian masyarakat adalah suatu kegiatan yang bertujuan membantu masyarakat tertentu dalam beberapa aktivitas tanpa mengharapkan imbalan dalam bentuk apapun. Secara umum program ini dirancang oleh berbagai universitas atau institut yang ada di Indonesia begitu pula di Universitas Pamulang (UNPAM) untuk memberikan kontribusi nyata bagi bangsa Indonesia, khususnya dalam mengimplementasikan kadar lingkungan kepada Masyarakat”.

Dalam kehidupan bersosialisasi karang taruna cukup berpengaruh bagi warga setempat Karang Taruna merupakan wadah pengembangan generasi muda nonpartisan, yang tumbuh atas dasar kesadaran dan rasa tanggung jawab sosial dari, oleh dan untuk masyarakat khususnya generasi muda di wilayah Desa/ Kelurahan atau komunitas sosial sederajat, yang terutama bergerak dibidang kesejahteraan sosial. Sebagai organisasi sosial kepemudaan Karang Taruna merupakan wadah pembinaan dan pengembangan serta pemberdayaan dalam upaya mengembangkan kegiatan ekonomi produktif dengan pendayagunaan semua potensi yang tersedia di lingkungan baik sumber daya manusia maupun sumber daya alam yang telah ada. 
Sebagai organisasi kepemudaan, Karang Taruna berpedoman pada Pedoman Dasar dan Pedoman Rumah Tangga di mana telah pula diatur tentang struktur pengurus dan masa jabatan di masing-masing wilayah mulai dari Desa/ Kelurahan sampai pada tingkat Nasional. Semua ini wujud dari pada regenerasi organisasi demi kelanjutan organisasi serta pembinaan anggota Karang Taruna baik dimasa sekarang maupun masa yang akan datang.

Seperti halnya yang saat ini sedang dilakukan oleh Karang Taruna dan Masyarakat dalam memasarkan hasil industri rumahannya yaitu kerajinan tangan. Industri rumahan saat ini menjadi kegiatan yang memiliki peran besar dalam membantu perputaran ekonomi rumah tangga. Bentuk kegiatan industri rumahan bermacam-macam, misalnya makanan, kerajinan, minuman dan lain-lain. Belum lama ini saya menemukan perkampungan di Kelurahan. Paku Jaya, Serpong Utara dimana di dalamnya para ibu rumah tangga, rata-rata membuat kerajinan tangan tas baik kecil sampai besar yang bahan bakunya dari sisa bungkus minuman kemasan instan seperti kopi, susu tas plastik belanja dari supermarket besar, dan lain-lain. Awalnya kegiatan ini hanya sebagai sambilan dan mengisi kesibukan, tetapi sekarang justru menjadi kegiatan yang bermanfaat dan menghasilkan.

Kegiatan ini diawali oleh Dosen dan Mahasiswa/i Dari Universitas Pamulang, yang memberikan pelatihan pada saat acara pertemuan Karang Taruna rutin di RT 004/RW022 (Rukun Warga) Kel. Paku Jaya, Serpong Utara setempat. Pesanan dari kalangan teman dan kerabat dekat mulai muncul. Setelah berjalannya waktu, kegiatan ini menjadi kegiatan serius yang ingin dijalani oleh para ibu untuk menambah dan mendukung perekonomian di rumah tangga. Masalah yang timbul adalah bagaimana menetapkan strategi pemasaran yang tepat agar produk industri rumah tangga ini dapat cepat dikenal dan menerima pesanan secara luas, karena selama ini komunikasi dan transaksi yang terjadi masih menggunakan sistem konvesional maupun tradisional, dari mulut ke mulut dan karena kenal saja.

Berdasarkan alasan di atas penulis tertarik untuk melakukan penelitian apakah sosial media bagian dari digital marketing yang digunakan, memberikan pengaruh terhadap volume penjualan industri rumahan mereka Kondisi ini dialami oleh para ibu Karang Taruna dan Masyarakat, khususnya ibu rumah tangga di RT. 004 RW. 022, Kel. Paku Jaya, Serpong Utara terutama mereka yang berpendapatan menengah ke bawah. Dimasa Pandemi. Dan Judul penelitian yang diangkat adalah "Penggunaan Digital Untuk Meningkatkan Pemasaran Produk Dimasa Pandemi Pada Karang Taruna Kelurahan Paku Jaya RT. 004 RW. 022, Kelurahan Paku Jaya, Kecamatan Serpong Utara, Kota Tangerang Selatan”.

\section{METODE PELAKSANAAN KEGIATAN}

Metode kegiatan yang dilakukan dalam rangka mensukseskan kegiatan pengabdian ini, yaitu:

a. Peralatan yang dibutuhkan untuk melaksanan kegiatan ini. Pada tahapan ini pelaksana memulai dengan melakukan koordinasi dengan instansiterkait.

b. Penentuan Lokasi. Pada tahap ini dilakukan kunjungan ke lokasi untuk menentukan tempat (lokasi). Dalam memilih lokasi, kamimempertimbangkan 
dengan jarak yang kami tempuh dari Universitas ke lokasi pengabdian.

c. Perancangan kebutuhan.

Adapun tahapan yang dilakukan dalam perancangan kebutuhan secara berurutan adalah sebagai berikut:

a. Perancangan materi mengenai pentingnya pengelolaan media Digital untuk pemasaran yang saat ini sedang banyak diminati

b. Perancangan materi bagaimana memasarkan produk dan jasa secara digitalakan membantu menjadikan bisnis lebih kompetitif.

c. Perancangan alat.

\section{HASIL DAN PEMBAHASAN \\ Pengertian Digital Marketing}

Digital marketing adalah suatu kegiatan pemasaran atau promosi sebuah brand atau produk menggunakan media digital atau internet. Tujuan digital marketing adalah untuk menarik konsumen dan calon konsumen secara cepat. Seperti yang kita tahu, penerimaan teknologi dan internet di masyarakat sangat luas sehingga tidak heran kegiatan pemasaran secara digital dijadikan pilihan utama oleh perusahaan-perusahaan. Menurut Purwana dkk (2017), digital marketing adalah aktivitas mempromosikan dan mencarikan pasar melalui media digital secara online dengan menggunakan berbagai sarana seperti jejaring sosial. Menurut Nadya (2016), digital marketing adalah pemasaran dengan menggunakan penerapan teknologi secara digital. Salah satu bentuk marketing digital dengan menggunakan media elektronik atau internet adalah internet marketing (e-marketing). Menurut Sanjaya dan Tarigan (2016), digital marketing adalah kegiatan marketing termasuk branding yang menggunakan berbagai media berbasis web seperti blog, website, email, adwords, ataupun jejaring sosial.

\section{Langkah-langkah Memulai Digital Marketing}

Banyak pelaku bisnis yang baru menyadari bahwa mereka perlu mengadopsi digital marketing untuk mampu menjangkau target pasar. Bukan tanpa alasan, hari ini cara masyarakat untuk mendapatkan produk dan mencari produk sudah mengalami perubahan, keputusan pembelian juga demikian.

Jika dahulu, konsumen dianggap pasif dan harus selalu dibombardir oleh iklan-iklan yang bersifat hard sell namun hari ini tidak demikian, konsumen sudah lebih aktif dan sudah bisa membedakan mana yang jelas-jelas iklan atau bukan.

\section{Manfaat Pemasaran melalui Media Digital}

1. Menghubungkan usaha yang dimiliki dengan Konsumen di Internet Saat ini konsumen sudah tak lagi mencari informasi mengenai suatu produk barang atau jasa melalui halaman iklan baris. Saat ini, setidaknya $80 \%$ konsumen menggunakan internet untuk memperoleh informasi mengenai produk barang atau jasa dengan lebih mudah dan nyaman. Dengan banyaknya alat dan channel yang tersedia dalam pemasaran digital, pemilik usaha dapat mencapai target konsumen mereka yang rata-rata menghabiskan waktu mereka mencari 
informasi melalui internet.

2. Menghasilkan Penjualan yang Tinggi Melalui digital marketing, Anda dapat menjangkau lebih banyak khalayak yang Anda targetkan. Anda juga dapat menghasilkan lead (prospek) dan mencapai peningkatan konversi (penjualan) sampai $24 \%$. Pemasaran digital 'membuka' jalan upaya pemasaran yang akan membuahkan hasil yang menguntungkan.

3. Membuat lebih Hemat Pemasaran Digital Gartnet mengeluarkan laporan yang menunjukkan bagaimana para pengusaha kecil kini sudah mendapatkan banyak keuntungan dari pemasaran digital. Contohnya saja, sebanyak 40\% dari mereka melaporkan adanya efisiensi biaya yang ada pada usaha mereka. Usaha kecil yang dimaksudkan disini adalah usaha atau perusahaan yang memiliki sumber daya terbatas. Pemasaran digital kemudian bisa membantu pemilik usaha, tidak hanya menghasilkan generasi dan konsumen baru, namun juga membantu menghemat pengeluaran pengusaha.

4. Mengaktifkan Layanan Pelanggan Real-Time Pemasaran digital menawarkan Anda adanya mekanisme respon konsumen atau pelanggan real-time, yang akan memberikan dampak besar pada keberhasilan usaha Anda menurut laporan dari eMarketer. Keuntungan dari chanel pelayanan yang disediakan oleh pemasaran digital diantaranya adalah menghasilkan pendapatan yang lebih besar, mempertahankan pelanggan dan memberikan kepuasan layanan terhadap konsumen.

5. Menjangkau Pengguna Mobile (Smartphone) Pemasaran digital membawa Anda memasuki area pasar raksasa, dimana kegiatan pemasaran digital melalui perangkat mobile menghasilkan hingga $34 \%$ dari keseluruhan trafik organik. Menurut eMarketer, teknologi mobile juga mempengaruhi perilaku pembelian konsumen tersebut. Data menunjukkan bahwa 91\% orang dewasa di Amerika Serikat selalu menggunakan perangkat mobile mereka setiap saat.

6. Membantu Menghasilkan Pendapatan Tinggi Konsumen yang melakukan transaksi secara online membutuhkan enam poin utama untuk meyakinkan mereka agar melakukan pembelian, setelah itu mereka bahkan bisa empat kali lebih banyak melakukan pembelian dari konsumen biasanya. Strategi pemasaran digital dikonfirmasi bisa mengasilkan peningkatan keuntungan 2,8 kali lebih besar bagi sebuah usaha dibandingkan dengan pemasaran tradisional.

7. ROI Menjadi Lebih Tinggi Dalam laporan HubSpot, terkonfiramsi bahwa pemasaran digital dapat membantu Anda untuk menghasilkan Cost-Per-Lead (CPL) yang lebih baik dibandingkan dengan pemasaran tradisional atau bahkan telemarketing.

8. Menjaga Posisi Anda Terhadap Pesaing Banyak merek dan usaha saat ini saling bersaing dengan campaign digital marketing mereka. Para pengusaha menggunakan bermacam-macam chanel termasuk display, PPC, dan penggunaan media sosial.

9. Membantu Anda Bersaing dengan Perusahaan Besar Tidak hanya membuat posisi Anda sejajar dengan pesaing, namun digital marketing juga memungkinkan Anda untuk bersaing head to head dengan merek dan 
perusahaan besar.

10. Mempersiapkan Anda untuk Era Internet of Things Gartner melaporkan bahwa pada tahun 2020 diperkirakan adanya 26 miliar gadget, smartphone, tablet, jam tangan, kacamata, sepatu dan peralatan lainnya yang akan saling terhubung dalam ekosistem online secara global yang akan membentuk era Internet of Things.

\section{KESIMPULAN}

Kegiatan seminar Penggunaan digital untuk meningkatkan pemasaran produk dimasa pandemi yang menggunakan social media sebagai sarana untuk menjalani indutri rumahannya. Media sosial yang paling banyak digunakan adalah Facebook (FB), Whatsaap (WA), Istagram (IG), Web site, dan Media online Shop. Manfaat yang paling dirasakan adalah komunikasi dengan Hampir semua peserta antusias dan merasakan manfaat pelatihan dari media Digital. Pelaksanaan pengabdian untuk peserta Karang Taruna RT. 004 RW. 022 Kel. Paku Jaya, Kec. Serpong Utara, Kota Tangerang Selatan ini dapat disimpulkan berhasil sampai tahap diskusi dengan menjawab permasalahan- permasalahan Media Digital untuk promosi yang paling baik karena bisa menampikan dan berbagi gambar lewat media Digital untuk promosi bisnis online masyarakat kel. Paku Jaya kepada pelanggan. Update informasi dapat dilakukan setiap waktu. Dan yang paling penting peningkatan volume penjualan rata-rata $100 \%$.

\section{DAFTAR PUSTAKA}

Arga Teriyan, et al. (2021). Strategi Bertahan di Masa Pandemi Covid-19. Jurnal Peradaban Masyarakat. 1(2). 29-32

ER, T., Listiawati, et al. (2021). The Effect Of Online Marketing And E-Service Quality On Purchase Decisions: An Emprirical Study On Online Shop. Turkish Journal of Physiotherapy and Rehabilitation, 32(3).

Erlangga, H. (2021). Effect Of Digital Marketing And Social Media On Purchase Intention Of Smes Food Products. Turkish Journal of Computer and Mathematics Education (TURCOMAT), 12(3), 3672-3678.

Haikal, H., et al. (2021). Penyuluhan Pemanfaatan Media Sosial Bagi Perkembangan Sumber Daya Manusia (SDM) Pada Masyarakat Desa. Jurnal PADMA: Pengabdian Dharma Masyarakat, 1(3).

Rawi, R. D. P., et al. (2019). Pelatihan Pembuatan Keripik Pisang Sebagai Sarana Peluang Bisnis Dan Kreatifitas Mahasiswa Fakultas Ekonomi Universitas Muhammadiyah Sorong. Abdimas: Papua Journal of Community Service, 1(2), 24-30.

Yuangga, K. D., et al. (2021). Penyuluhan Management Creative Dalam Mendongkrak Inovasi Dan Memajukan Usaha Pada Sai Silver Bali. Jurnal Pengabdian Dharma Laksana, 4(1), 46-52. 